\title{
Silver book is golden
}

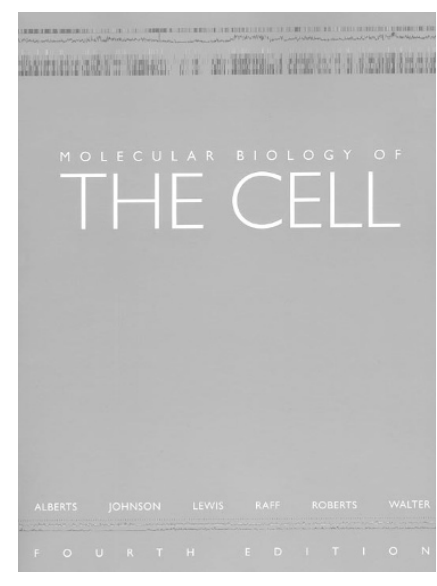

Molecular Biology of the Cell, Fourth Edition

by B. Alberts, A. Johnson, J. Lewis, M. Raff, K. Roberts and P. Walter

Garland Science $\cdot 2002$

Hardback $\mathfrak{£} 75 / \$ 24.95$

Paul Martin

$\mathrm{T}$ he first edition of Molecular Biology of the Cell came out the year before I began my $\mathrm{PhD}$ - I bought a waterdamaged copy of this gem at half price from a clumsy bookstore and was immediately taken by its novelty and readability. My fellow students and I loved the lucid text, the clear schematic diagrams and the short, snappy punchlines telling us all that was important in each new section. All bioscientists and students are now completely familiar with 'concept headings' and many use them when writing up primary papers, but nearly 20 years ago they felt like a longawaited innovation that would make learning so much easier. And it certainly is the case that the first edition, and all subsequent versions of this pioneering book, have been a fabulous teaching aid, covering the diverse topics of cell and molecular biology.

However, almost 20 years later, much has changed. The first edition seemed to cope easily, and in sufficient detail, with most of what was known then, operating as a launch pad into the primary literature of the time (or at least that was the illusion I had as an undergraduate in those days), but over recent years, there has clearly been such an explosion in our knowledge of how cells and tissues are built and work, and there is just such a vast array of literature and numerous new branches of all the niche areas of cell biology that there barely seems the space in one book to satisfactorily summarise it all - surely just one chapter isn't sufficient to cover all aspects of modern developmental biology, just as one page is barely sufficient space to provide an overview how Rho family small GTPases regulate the actin cytoskeleton. But here the expansion of journals focusing on reviews, and the introduction of review articles in many primary journals, comes to the rescue of Molecular Biology of the Cell Fourth Edition. Rather than the end-of-chapter reading lists that are dominated by primary papers, as they used to be, this edition largely directs readers to the best of the review articles for a digested version of their cho- sen topic before they choose to feast on primary papers! I think this two-step introduction to the science will work well until this book is 2 or 3 years old and the cited review articles are out of date. Then, tutors will need to be on their toes in supplementing the reading lists, or perhaps Garland Science might consider updating these yearly on the web?

Just as with each previous edition of Molecular Biology of the Cell, it is clear that the authors have not been lazy in overhauling each chapter to incorporate as much of the new information as space allows. Their attention to detail and accuracy is obvious and all sections feel fresh and exciting. I'm glad that the authors still find space for little bits of seemingly uneccessary anecdotal text titbits or fun images - it is good that they included a picture of the "taxol tree" for example - without these asides, the text might be too dense and off-putting to students. Some of the sections are not just revamped, but are brand new. The new chapter on pathogens, infection and innate immunity is a welcome addition, not just because of the huge strides made in this area and its clear clinical significance, but also because more and more eukaryotic cell biologists are finding superb clues as to how the machineries of their cells are regulated by watching how a parasitic microbe hijacks that machinery for its own propogation.

During this gestation of this edition, the genome sequences of several key model organisms have been published and most chapters (and even the cover!) reflect on how this new resource will speed up our understanding of the molecular genetics underpinning all cell activities. Several times, I wondered whether it might have been nice to find a section that highlights the strategies used for sequencing genomes and the subsequent annotation, for example, of the Drosophila melanogaster genome. I think this story might have been interesting to students whose future scientific careers will be so dependent on this new mine of information.
In recent years, cell biology has also been revolutionised by tools that allow live imaging of the dynamic events of cellular behaviour. In particular, green fluorescent protein (GFP)-tagged proteins have advanced our ability to visualize cells 'doing their stuff', both in vitro and in vivo, and Molecular Biology of the Cell gives us a taster of some of this new video data, together with several useful animations on a free CD tucked inside the cover. Unfortunately, this CD, although a great first step, simply highlights how much more of the same we will want our students to have access to and how much more integrated we need this to be with the mother text. Best, of course would be for a student to be able to play the excellent GFP-cadherin adhesion movie showing adhesions forming between epithelial cells as a subconfluent population grows and the cells make contacts with one another - and then to be able to click on a supplementary text box for more detailed information and a schematic, and maybe an electron microscope image to show them the ultrastructure of such a junction. I guess this will be the target of a 5 th edition.

I have to say, I couldn't wait to get my hands on this new edition and I have not been disappointed. Initially, I found the silver cover garish, but I'm learning to live with it now! The authors feature again on the back cover with their Abbey Road theme, accompanied this time by a motley collection of heroes, mentors and pals. They all look a little older than when the 1 st edition hit us by storm, but still they come up with the goods. Molecular Biology of the Cell was the first, and still is the best, example of this genre of undergraduate text book that attempts to cover the vast topic of cell and molecular biology. Paul Martin is in the Department of Anatomy and Developmental Biology, University College London, London, WC1E 6BT, UK

e-mail:paul.martin@ucl.ac.uk 